\title{
Hereditary angioedema and Allergic bronchopulmonary aspergillosis: an unexpected association
}

\author{
Angioedema hereditário e Aspergilose broncopulmonar alérgica: uma associação inesperada
}

\author{
Laise Fazanha Sgarbi', Sérgio Duarte Dortas-Junior², Maria Luiza Oliva Alonso², \\ Alfeu Tavares França², Solange Oliveira Rodrigues Valle ${ }^{2}$
}

\section{ABSTRACT}

Hereditary angioedema (HAE) is a rare autosomal dominant disorder, Allergic bronchopulmonary aspergillosis (ABPA) is a lung disease involving hypersensitivity to the fungi Aspergillus fumigatus which occur in susceptible patient with asthma or cystic fibrosis, also considered a rare disease. We report a case of $\mathrm{HAE}$ and ABPA in a single patient. HAE diagnosis was confirmed: $\mathrm{C} 4=$ $3 \mathrm{mg} / \mathrm{dL}, \mathrm{C} 1 \mathrm{INH}<2.8 \mathrm{mg} / \mathrm{dL}$ - nephelometry. Former lung function showed elevation RV and RV/FVC, suggesting small airways lung disease. Positive skin prick test to Aspergillus fumigatus (03 $\mathrm{mm}$ ); total serum IgE level 3,100 IU/mL (nephelometry - BNII Siemens), eosinophilia $11 \%\left(528 / \mathrm{mm}^{3}\right)$ and specific $A$. fumigatus IgG antibodies 6,8 mgA/L (FEIA - fluorenzymeimmunoassay ThermoFisher) and Chest CT showed mucoid impaction of the bronchi, consistent to current ABPA. Controlling ABPA could prevent and reduce angioedema attacks, and lung structural damage. Early diagnosis and treatment of both diseases should be emphasized to reduce mortality and morbidity

Keywords: Hereditary angioedema types I and II, allergic bronchopulmonary aspergillosis, asthma, bradykinin, hereditary angioedemas.

\section{Introduction}

Hereditary angioedema (HAE) is a rare autosomal dominant disorder. Different forms of HAE are currently recognized and genetically identifiable, the most common mutations occurring in the

\section{RESUMO}

Angioedema hereditário (AEH) é uma doença autossômica dominante; aspergilose broncopulmonar alérgica (ABPA) é uma doença de hipersensibilidade pulmonar relacionada ao esporo de Aspergillus fumigatus, mais suscetível em pacientes com asma e fibrose cística, ambas são consideradas doenças raras. Apresentamos um caso de AEH e ABPA em um paciente. $O$ diagnóstico de $\mathrm{AEH}$ foi confirmado com exames laboratoriais: $\mathrm{C} 4=3 \mathrm{mg} / \mathrm{dL}, \mathrm{C} 1 \mathrm{INH}<2,8 \mathrm{mg} / \mathrm{dL}$ - nefelometria. Prova de função pulmonar evidenciou aumento de VR e VR/CVF, sugerindo doenças de pequenas vias aéreas. Teste de puntura positivo para A. fumigatus $(03 \mathrm{~mm}$ ); $\mathrm{IgE}$ total $=3.100 \mathrm{IU} / \mathrm{mL}$ (nefelometria - BNII Siemens), eosinofilia $11 \%\left(528 / \mathrm{mm}^{3}\right)$ e IgG específica para $A$. fumigatus $6,8 \mathrm{mgA} / \mathrm{L}$ (FEIA - ThermoFisher), TC de tórax evidenciou impactação mucoide, consistente com ABPA. Controlar ABPA pode prevenir e reduzir as crises de angioedema e os danos ao tecido pulmonar. O diagnóstico precoce de ambas as doenças deve ser enfatizado para reduzir a morbimortalidade.

Descritores: Angioedema hereditário tipos I e II, aspergilose broncopulmonar alérgica, asma, bradicinina, angioedemas hereditários.
SERPING1 gene, leading to quantitative [HAE type $\mathrm{I}(\mathrm{HAE}-1)$ ] or qualitative [HAE type II(HAE-2)] deficiency of $\mathrm{C} 1$ esterase inhibitor $(\mathrm{C} 1-\mathrm{INH}){ }^{1}$ Allergic bronchopulmonary aspergillosis (ABPA) is

1. Centro de Especialidades Médicas, Ambulatório de Alergia e Imunologia - Três Lagoas, MS, Brazil.

2. Hospital Universitário Clementino Fraga Filho (HUCFF-UFRJ), Serviço de Alergia e Imunologia - Rio de Janeiro, RJ, Brazil. 
a lung disease involving hypersensitivity to the fungi Aspergillus fumigatus ( $A f$ ) which occur in susceptible patient with asthma or cystic fibrosis. ${ }^{2}$

HAE-1 and HAE-2 with a combined estimated prevalence of approximately $1: 50,000$ is an autosomal dominant disease, although $25 \%$ of patients may have no family history. ${ }^{1}$

ABPA affects approximately $1 \%$ through $15 \%$ of cystic fibrosis patients. ${ }^{2}$ One study calculated that $2.5 \%$ of adults who have asthma also have ABPA, which is approximately 4.8 million people worldwide. In other studies, ABPA was detected in $25 \%$ to $37 \%$ of asthmatics with a positive skin prick test to $A f{ }^{3}$

\section{Case report}

A 07-year-old boy who presented to Immunology Service for HAE screening, since his father and grandmother had been formerly diagnosed HAE-1. His parents reported recurrent lips swelling, without wheals, during about 48-72 hours. Swellings were not responsive to antihistamines and corticosteroids. HAE diagnosis was confirmed ( $\mathrm{C} 4=3 \mathrm{mg} / \mathrm{dL}, \mathrm{C} 1 \mathrm{INH}$ $<2.8 \mathrm{mg} / \mathrm{dL}$ - nephelometry) and he was prescribed tranexamic acid $250 \mathrm{mg} /$ day. Long-term prophylactic treatment was interrupted at the age of 10 as HAE was controlled, and on demand therapy (plasma-derived C1-inhibitor concentrate) was prescribed.

At first evaluation, he also reported sneezing, nasal itching, running nose, dyspnea and wheezing. $\mathrm{He}$ was diagnosed with asthma and allergic rhinitis and therapy initiated. Patient ended up with uncontrolled moderate asthma because of nonadherence to treatment. At 17 years old, patient performed a spirometry that showed FEV1 (Forced Expiratory Volume in first second) and FVC (Forced Vital Capacity) reduction with negative reversibility testing, but the VC (Vital Capacity) normalized. Former lung function showed elevation RV (Residual Volume) and RV/FVC, suggesting small airways lung disease. Positive skin prick test to Aspergillus fumigatus (03 mm); total serum IgE level 3,100 IU/mL (nephelometry - BNII Siemens), eosinophilia 11\% $\left(528 / \mathrm{mm}^{3}\right)$ and specific $A$. fumigatus $\lg \mathrm{G}$ antibodies $6,8 \mathrm{mgA} / \mathrm{L}$ (FEIA - fluorenzymeimmunoassay ThermoFisher) and Chest CT showed mucoid impaction of the bronchi, consistent to current ABPA diagnostic criteria. ${ }^{3}$ Inhaled corticosteroids and LABA were prescribed with disease control.

\section{Discussion}

HAE is a disabling, potentially fatal condition characterized by recurrent episodes of swelling. A failure of regulation of the kallikrein-kinin system by $\mathrm{C} 1-\mathrm{INH}$ to prevent bradykinin (BK) formation is recognized, which increases endothelial permeability (by the interaction to B2 receptor) and leads to recurrent episodes of swelling involving the deeper layers of the skin and/or submucosal tissue. ${ }^{4,5}$

The lectin pathway, other mechanisms for the activation of the complement system in HAE have been suggested, and may result in upregulation of $B 2$ and $\mathrm{B} 1$ receptor. As with the other serine proteases 1 and 2 are inhibited by $\mathrm{C} 1-\mathrm{INH}$ and provides an unregulated production of angioedema. ${ }^{5}$

During angioedema attacks the circulating levels of BK, markers of endothelial activation, prothrombin fragments, D-dimer, cytokines (e.g., TNF- $\alpha$ and IL-8), as well as neutrophil count and neutrophilderived factors (e.g., elastase, myeloperoxidase, pentraxin 3) are increased when compared with symptom-free periods in C1-INH-HAE patients. ${ }^{4,5}$ ABPA is caused by hypersensitivity to Af Antigens. ${ }^{2}$ In susceptible hosts, repeated inhalation of Aspergillus spores can cause an allergic response. These spores are trapped in the fluids and mucus lining of the epithelial surface, germinate, leading hypha growth and release a variety of proteins allergens and proteases that leads to a robust inflammatory response. Innate lymphoid cells and Th2 cells are activated and produce cytokines (IL-4, IL-5 and IL-13), that stimulate inflammation. This reaction is mainly an immunoglobulin E ( $\mathrm{gEE}$ ) mediated hypersensitivity reaction (increased total serum IgE levels and $A f$ specific IgE antibodies production, mast cells degranulation and exacerbated eosinophilic response). Both type III and type IV, immunoglobulin $\mathrm{G}$ (IgG) mediated immune complex and cell-mediated hypersensitivity reactions have also been seen in ABPA immunopathogenesis. ${ }^{2,3}$

ABPA Th2 response causes substantial local inflammatory reaction, leading to structural lung damage, bronchiectasis and pulmonary fibrosis. It also predisposes the patient to the development of respiratory infections. ${ }^{2,6}$ Infections have been well described in literature as one of the possible triggers of angioedema attacks. We believe that ABPA complications, such as recurrent exacerbations, as well as respiratory infections might easily trigger angioedema attacks. As well as HAE attacks might 
trigger bronchospasm and/or aggravate smooth muscle structural damage.

In allergic mild asthma is well reported an overexpression of B2 and B1 receptor, and in acute airway inflammation pathway kinins are activated and B2 receptor is upregulated. ${ }^{7}$ B2 activation can induces bronchospasm, endothelial permeability, mucus secretion, cholinergic nerve stimulation. B1 and B2 activation is usually associated to eosinophil, neutrophil recruitment, Type-2 cytokines (due to IL-4/IL-13), kinins, releasing of various inflammatory mediators (activated epithelial, endothelial cells, endothelial-nitric oxide synthase, vascular endothelial growth factor, fibroblasts, PGE2, II-8) a cascade implicated in airway chronic inflammation, which drives remodeling airway. ${ }^{7}$

If this patient presents a HAE attack, BK levels should increase, and B2 receptor activates driven to this airway inflammation, which we believe would be a severe bronchoconstriction, the use of icatibant would be the best choice acute treatment. ${ }^{7}$ Although, it is related epithelia-derived PGE2 from bradykinin stimulation reduces smooth muscle contraction. The participation of PGE2 in allergic airway response depends on signaling receptor, is not exactly clear. Maybe in this case is acting controlling eosinophilia, reducing Th2 response. ${ }^{8,9}$

To the best of our knowledge, it's the first report of the association of these immunologic entities. Regardless of heterogeneity of both ABPA and HAE bradykinin and Th2 responses are involved in both disorders due to airway chronic inflammation contact system. ${ }^{10}$

Therefore, it is possible to hypothesize that this HAE patient might present a worse evolution, so controlling ABPA could prevent and reduce angioedema attacks, and lung structural damage. Early diagnosis and treatment of both diseases should be emphasized to reduce mortality and morbidity.

\section{References}

1. Maurer M, Magerl M, Ansotegui I, Aygören-Pürsün E, Betschel $\mathrm{S}$, Bork $\mathrm{K}$, et al. The international WAO/EAACl guideline for the management of hereditary angioedema-The 2017 revision and update. Allergy. 2018 Aug;73(8):1575-96.

2. Knusten, A. Allergic bronchopulmonary aspergillosis in asthma. Expert Review of Clinical Immunology. 2017;b13:1:11-4.

3. Patel AR, Patel AR, Singh S, Singh S, Khawaja I. Treating Allergic Bronchopulmonary Aspergillosis: A Review. Cureus. 2019;11(4):e4538.

4. Loffredo S, Ferrara AL, Bova M, Borriello F, Suffritti C, Veszeli N, et al. Secreted Phospholipases A2 in Hereditary Angioedema With C1-Inhibitor Deficiency. Front Immunol. 2018;9:1721.

5. Wedner HJ. Hereditary angioedema: Pathophysiology (HAE type I, HAE type II, and HAE nC1-INH). Allergy Asthma Proc. 2020 Nov 1;41(Suppl 1):S14-S17.

6. Muthu V, Prasad KT, Sehgal IS, Dhooria S, Aggarwal AN, Agarwal R. Obstructive lung diseases and allergic bronchopulmonary aspergillosis. Curr Opin Pulm Med. 2021;27(2):105-12.

7. Ricciardolo FLM, Folkerts G, Folino A, Mognetti B. Bradykinin in asthma: Modulation of airway inflammation and remodelling. Eur J Pharmacol. 2018 May 15;827:181-188. doi: 10.1016/j. ejphar.2018.03.017.

8. Lee K, Lee SH, Kim TH. The Biology of Prostaglandins and Their Role as a Target for Allergic Airway Disease Therapy. Int J Mol Sci. 2020 Mar 8;21(5):1851.

9. Peebles RS Jr. Prostaglandins in asthma and allergic diseases. Pharmacol Ther. 2019 Jan;193:1-19.

10. Brunnée T, Reddigari SR, Shibayama Y, Kaplan AP, Silverberg M. Mast cell derived heparin activates the contact system: a link to kinin generation in allergic reactions. Clin Exp Allergy. 1997;27.

No conflicts of interest declared concerning the publication of this article.

Corresponding author:

Solange Oliveira Rodrigues Valle

E-mail: solangervalle@gmail.com 